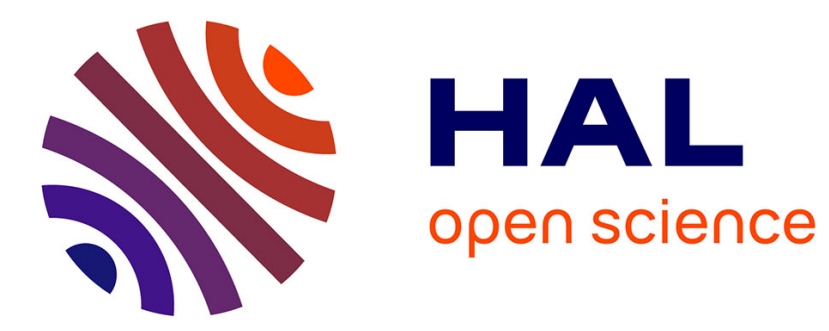

\title{
Enzymatic and fluorometric determination of triacylglycerols in cow milk and other opaque matrices
}

Torben Larsen, Mette Krogh Larsen, Nicolas N.C. Friggens

\section{To cite this version:}

Torben Larsen, Mette Krogh Larsen, Nicolas N.C. Friggens. Enzymatic and fluorometric determination of triacylglycerols in cow milk and other opaque matrices. Food Chemistry, 2011, 125 (3), pp.1110-1115. 10.1016/j.foodchem.2010.09.104 . hal-01019521

\section{HAL Id: hal-01019521 \\ https://hal.science/hal-01019521}

Submitted on 29 May 2020

HAL is a multi-disciplinary open access archive for the deposit and dissemination of scientific research documents, whether they are published or not. The documents may come from teaching and research institutions in France or abroad, or from public or private research centers.
L'archive ouverte pluridisciplinaire HAL, est destinée au dépôt et à la diffusion de documents scientifiques de niveau recherche, publiés ou non, émanant des établissements d'enseignement et de recherche français ou étrangers, des laboratoires publics ou privés. 
Provided for non-commercial research and education use. Not for reproduction, distribution or commercial use.

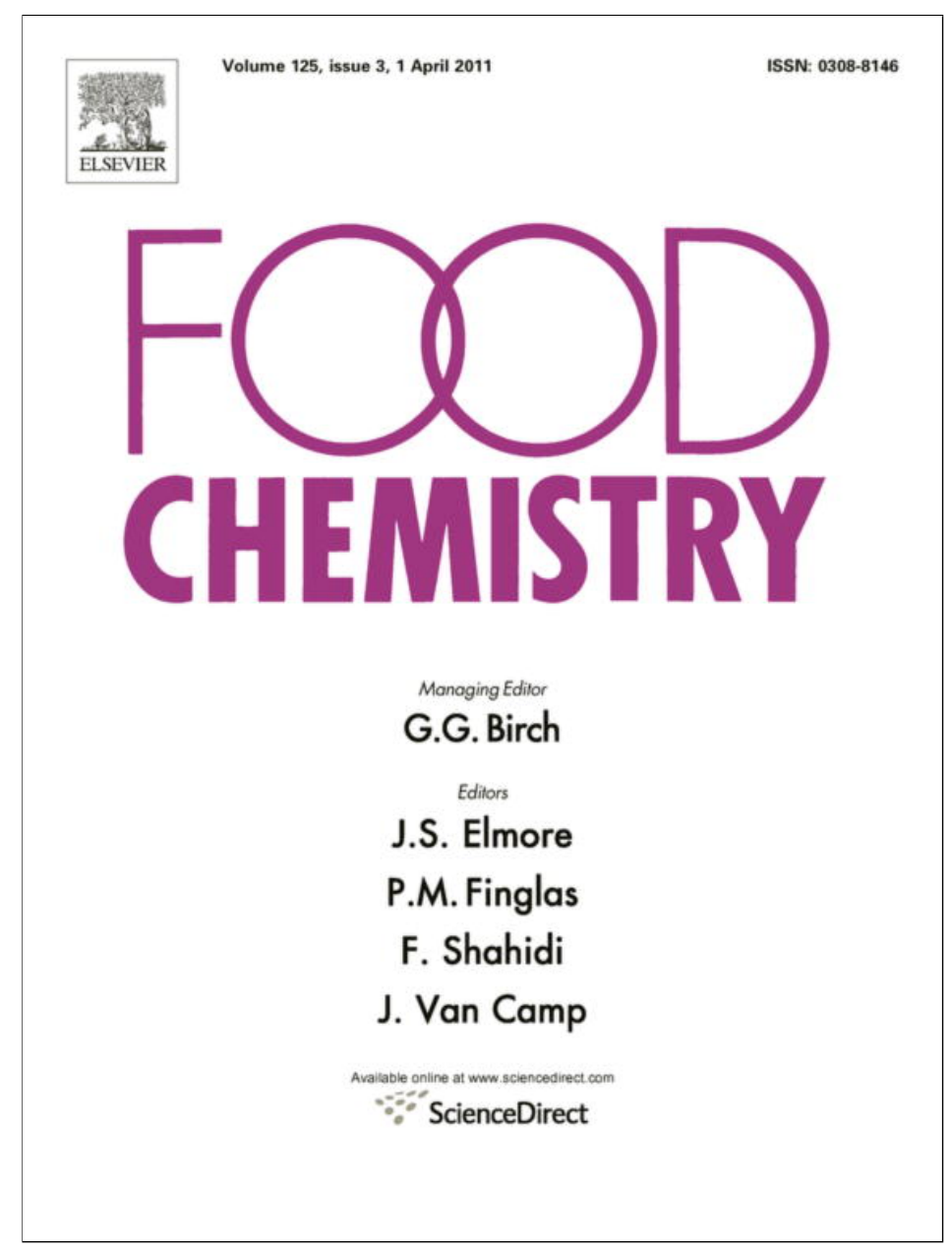

This article appeared in a journal published by Elsevier. The attached copy is furnished to the author for internal non-commercial research and education use, including for instruction at the authors institution and sharing with colleagues.

Other uses, including reproduction and distribution, or selling or licensing copies, or posting to personal, institutional or third party websites are prohibited.

In most cases authors are permitted to post their version of the article (e.g. in Word or Tex form) to their personal website or institutional repository. Authors requiring further information regarding Elsevier's archiving and manuscript policies are encouraged to visit:

http://www.elsevier.com/copyright 
Analytical Methods

\title{
Enzymatic and fluorometric determination of triacylglycerols in cow milk and other opaque matrices
}

\author{
Torben Larsen $^{\mathrm{a}, *}$, Mette Krogh Larsen ${ }^{\mathrm{a}}$, Nic C. Friggens ${ }^{\mathrm{b}}$ \\ ${ }^{a}$ Aarhus University, Faculty of Agricultural Sciences, P.O. Box 50, 8830 Tjele, Denmark \\ ${ }^{\mathrm{b}}$ INRA UMR Modélisation Systémique de la Nutrition des Ruminants, AgroParisTech, 16 rue Claude Bernard, Paris 75005, France
}

\section{A R T I C L E I N F O}

\section{Article history:}

Received 9 December 2009

Received in revised form 23 June 2010

Accepted 28 September 2010

\section{Keywords:}

Milk fat

TAG

Enzymatic-fluorometric determination

\begin{abstract}
A B S T R A C T
The fat content of milk is an important indication of quality, both economically and physiologically. Existing analytical methods of milk fat are based on physical determination, i.e. gravimetric determination or near infrared spectroscopy (IR). Triacylglycerols (TAG) constitute up to $98 \%$ of total fat in milk. The present study describes a new method for determination of triacylglycerols in milk. The present method is a chemical, i.e. enzymatic-fluorometric assessment of glycerol, the content of TAG is consequently given in mol per litre. The method demonstrates a good accuracy and precision and the correlation with standard IR methods shows a fine association between the different assessment methods ( $n=228 ; r=0.905)$. Fatty acid profiles of sixty individual milk samples indicate that parameters co-linearly connected to specific fatty acids may explain a considerable amount of the variation between the methods. Furthermore, discrepancies between the present method and the established IR method may partly be due to the fact that IR spectroscopy is calibrated individually against gravimetric methods not taking fatty acid profiles and thereby molar weight of TAG into account.
\end{abstract}

(c) 2010 Elsevier Ltd. All rights reserved.

\section{Introduction}

The lipid content of cow's milk varies with such factors as diet, breed, stage of lactation, number of lactations and season of the year. In general, however, the fat content lies within 30-120 $\mathrm{g} \mathrm{l}^{-1}$ (Davies, Holt, \& Christie, 1983). The main lipid class (up to 98\%) consists of triacylglycerols (TAG), one glycerol molecule covalently connected to three fatty acids, and this is accompanied by small amounts of diacylglycerols and monoacylglycerols, cholesterol, non-esterified fatty acids and phospholipids. In addition to the main lipid classes, small amounts of hydrocarbons, carotenoids, sterols, $\boldsymbol{\alpha}$-tocopherol and various glycerol ethers have been found in milk (Christie, 1994; Kuzdzal-Savoie, Kuzdral, Langlois, \& Trehin, 1973).

Some $95 \%$ or more of the total lipids in milk are present in the milk fat globule fraction, and $95 \%$ or more of the lipids in the globule are TAG. Lipids in the milk serum are present primarily in a heterogeneous fraction of membranes and fractions hereof; phospholipids and TAG comprise most of the lipids in milk serum (MacGibbon \& Taylor, 2006).

Milk fat globules range from 0.2 to $15 \mu \mathrm{m}$ in diameter, with a volume-weighted diameter of about $4 \mu \mathrm{m}$ (Walstra, 1995). Natural milk fat globules are surrounded by a complex, biological membrane, the milk fat globule membrane (MFGM). The native

\footnotetext{
* Corresponding author. Tel.: +45 899911 57; fax: +45 89991500

E-mail address: Torben.Larsen@agrsci.dk (T. Larsen).
}

MFGM consists of a complex mixture of proteins, phospholipids, glycoproteins, triacylglycerols, cholesterol, enzymes and other minor components (Mather, 2000; McPherson \& Kitchen, 1983; Patton \& Keenan, 1975). The structure of the MFGM is multilayered, where polar molecules on the outer surface provide the water solubility and hence prevent aggregation and coalescence of milk fat (Danthine, Blecker, Paquot, Innocente, \& Deroanne, 2000; Evers, 2004; Lopez, Madec, \& Jimenez-Flores, 2010; Rombaut \& Dewettinck, 2006).

Cow's milk lipids in particular contain a much wider range of fatty acids than has been reported for the lipids from any other tissue (Davies et al., 1983), Patton and Jensen (1974) list 437 different fatty acids, characterised from cow's milk. The known acids include all the normal saturated components from $C_{2}$ to $C_{28}$, branch-chain acids from $C_{11}$ to $C_{26}$, cis- and trans monoenoic and polyenoic acids and various isomers of these, and keto and hydroxyl fatty acids. However, the quantitative majority of fat is made up by only 12 15 fatty acids incorporated in TAG. The frequency of common fatty acids $\left(C_{4}\right.$ to $\left.C_{18}\right)$ incorporated in cow's milk is variable due to stage of lactation and diet. Numerous studies have demonstrated that cow ration may influence the mammary cell synthesis of fatty acids (de novo synthesis of short and medium length chains) versus the fatty acids mobilised from the peripheral adipose tissues (medium to long chain acids). However, in broad terms, on a weight percentage basis, $C_{14: 0}, C_{16: 0}, C_{18: 0}$, and $C_{18: 1}$ fatty acids constitute in the vicinity of $80 \%$ of the milk fat, whilst e.g. $\mathrm{C}_{4}$ (butyric acid) only accounts for approximately 3-4\%. Conversely, on a molar basis, the short chain fatty acids make up a considerable 
number of molecules incorporated in milk fat due to their lower molecular weight, i.e. $\mathrm{C}_{4}$ to $\mathrm{C}_{10}$ represent $22 \%$ of fatty acids (Parodi, 1982). The final composition of the individual acids in the TAG molecule will determine the molar weight of the molecule. Theoretically, single TAG in the milk will exist, having molar weights between 400 and $1000 \mathrm{Da}$, however, the molar weight of composite milk often ranges between 680 and 800 .

The positional distribution of fatty acids on the glycerol molecule seem to vary, often depending upon the specific acid. Butyric acid and hexanoic acid seems preferentially to be linked to the sn-3 position whilst $C_{16: 0}$ (palmitate) preferentially is linked to sn-1 and sn-2 (Christie \& Clapperton, 1983; Parodi, 1982). The specific distribution of fatty acids in the triacyl molecule may very well be of importance in the enzymatic lipolysis.

The fat content of milk is an important indication of quality, both economically and physiologically. In the dairy industry, the milk fat is most often determined using rapid mid-infra-red methods, i.e. spectrometric methods (IDF, 2000). These methods, however, regularly have to be calibrated against reference methods, which is more labour intensive and costly. Several methods have been developed, where the essential step is the extraction of milk fat with nonpolar solvents and subsequent gravimetric determination of fat. Here, the Röse-Gottlieb method has most likely obtained the greatest attention (IDF, 1996). The "Gerber Method", or Acid-Butyrometric method (Gerber, 1891) is one of the traditionally used methods, because it is simple, inexpensive and suitable for a relatively high number of samples per day. Nevertheless, the determination cannot be automated, involves strong acids, and requires relatively experienced technicians. Numerous other methods have been suggested to measure the milk fat content or to harmonise, automate or simplify the reference methods to the quick methods used in the dairy business. Common to all fat determinations is that they are based on physical methods and they intend to determine the total fat content rather than the TAG content although the TAG constitutes more than $97 \%$ of total milk fat.

The present paper describes a chemical method for determination of TAG in milk or other non-transparent matrices. The access to the milk TAG, mainly within the MFGM, is mediated by moderate heat treatment, detergents and the addition of phospholipase C (EC 3.1.4.3). TAG molecules are hydrolysed by lipoprotein lipase (EC 3.1.1.34) and lipase (EC 3.1.1.3) to free fatty acids and glycerol. The glycerol unit is subsequently oxidised by glycerol dehydrogenase (EC 1.1.1.6) to dihydroxy acetone, and the cofactor NAD ${ }^{+}$is concomitantly reduced to $\mathrm{NADH}+\mathrm{H}^{+}$. $\mathrm{NADH}+\mathrm{H}^{+}$equivalently reduces the non-fluorescent resazurin to resorufin mediated by the enzyme diaphorase (EC 1.6.99._). The developed resorufin is terminally estimated by its fluorescense compared with a standard curve. The present TAG analysis determines the molar concentration of TAG.

\section{Materials and methods}

\subsection{Milk samples}

Milk samples were collected at random from daily milking on the local research farm which was housing both Danish FresianHolstein and Jersey breeds. Fresh milk was brought to the laboratory every morning. Milk samples were heated in a water bath at $75^{\circ} \mathrm{C}$ for $10 \mathrm{~min}$ before analyses.

\subsection{Reagents}

Diluent: A $0.2 \%$ Triton X-100 solution containing $12 \mathrm{mM}$ bile acids (FLUKA 48305).

Reagent 1: lipoprotein lipase (EC 3.1.1.34; Toyobo Enzymes); lipase (EC 3.1.1.3; FLUKA 62285); phospholipase C (EC 3.1.4.3; Sig- ma P7633) in Pipes buffer, $\mathrm{pH} 7.40,60 \mathrm{mM}$. The enzyme activities were $9.5 ; 6.1$; and $0.23 \mathrm{U} / \mathrm{ml}$, respectively.

Reagent 2: Na,K-carbonate buffer, $100 \mathrm{mM}, \mathrm{pH} 10.3$ with glycerol dehydrogenase (EC 1.1.1.6; Toyobo Enzymes), $10.4 \mathrm{U} / \mathrm{ml}$; $\left(\mathrm{NH}_{4}\right)_{2} \mathrm{SO}_{4}, 28 \mathrm{mM} ; \beta-\mathrm{NAD}^{+}$(MW 717.5), $6.3 \mathrm{mM}$.

Reagent 3: phosphate buffer, $100 \mathrm{mM}$, pH 7.4 containing resazurin (Sigma R-2127) $2.55 \mathrm{mM}$; and diaphorase enzyme (EC 1.6.99._, Toyoba Enzymes) $9 \mathrm{U} / \mathrm{ml}$.

\subsection{Analytical procedure}

Dosage and dilution of sample and addition of reagents were performed in a robotic system (Biomek ${ }^{\circledR} 2000$; Beckman Coulter).

(a) Milk samples (standards and control samples) distributed in a 96-well micro plate, were initially diluted $1+9$ with diluent.

Fifty micro litre reagent 1 was pipetted into the wells; thirty micro litre (diluted) milk was pipetted on top.

The plate was sealed/closed with a lid and incubated for 50 min at $40{ }^{\circ} \mathrm{C}$ (incubation 1 ).

(b) Eighty micro litre reagent 2 was added to the wells, the plate was incubated for another $20 \mathrm{~min}$ at $40^{\circ} \mathrm{C}$ (incubation 2).

(c) One hundred and twenty micro litre reagent 3 was added to the wells, the plate was incubated further for $50 \mathrm{~min}$ at $40{ }^{\circ} \mathrm{C}$ (incubation 3).

(d) The reaction was measured as development of fluorescence (emission at $590 \mathrm{~nm}$ ) after excitation at $544 \mathrm{~nm}$ light compared with a standard curve on the same plate.

\subsection{Chronological chemistry of the analysis}

\subsubsection{Step a. (enzymatic degradation of phospholipids and TAG)}

Diluted milk (30 $\mu \mathrm{l})$ sample was mixed with $50 \mu$ l enzyme solution (1), containing lipoprotein lipase, lipase and phospholipase $\mathrm{C}$ in PIPES buffer, pH 7.4. pH 7.4 in the medium is an acceptable compromise for the optimal conditions of the three enzymes. Incubation at $40{ }^{\circ} \mathrm{C}$ is correspondingly an effective temperature, not challenging the temperature stability of the enzymes. The phospholipase $C$ is expected to hydrolyse phospholipids (in the milk fat globule membrane and in milk serum) on the glycerol side of the P-lipid, thereby producing diacylglycerols and free "P-side chains". The lipoprotein lipase and the lipase enzymes are further expected to liberate the fatty acids from the glycerol backbone of TAG and diacylglycerols (hydrolyse TAG). The products are free glycerol and free fatty acids.

\subsubsection{Step $b$. (enzymatic oxidation of glycerol and development of $\left.\mathrm{NADH}+\mathrm{H}^{+}\right)$}

Eighty micro litre of reagent $\mathbf{2}$ was pipetted on top of the "up till now" reaction medium. The glycerol dehydrogenase enzyme in the reagent has a pH optimum between 9 and 11 . The $100 \mathrm{mM}$ carbonate buffer, $\mathrm{pH} 10.3$, following the enzyme will force $\mathrm{pH}$ in the alkaline direction (calculated to $\mathrm{pH}$ 9.7). The oxidative degradation is stimulated by $\mathrm{NH}_{4}{ }^{+}$and $\mathrm{K}^{+}$which are provided by the $\mathrm{K}$-phosphate and carbonate buffers used and ammonium sulphate in reagent 2 (both approximately $25 \mathrm{mM}$ in the reaction medium). $\mathrm{NAD}^{+}$is concomitantly reduced to $\mathrm{NADH}+\mathrm{H}^{+}$when glycerol is oxidised to dihydroxyacetone.

\subsubsection{Step c. (reduction of resazurin to resorufin by $\mathrm{NADH}+\mathrm{H}^{+}$and diaphorase)}

The addition of $120 \mu$ of reagent 3 brings pH down to approximately 8.0 to 8.2 which is more in accordance with the optimum of the used diaphorase enzyme. Diaphorase mediates the reduction of resazurin to resorufin via $\mathrm{NADH}+\mathrm{H}^{+}$whereby $\mathrm{NAD}^{+}$is regener- 
ated. Resazurin is only very marginally fluorescent whilst resorufin is highly fluorescent. The amount of resorufin produced in the process was measured by fluorometry (emission at $590 \mathrm{~nm}$ ) after excitation at $544 \mathrm{~nm}$ light and compared with a standard curve. The fluorometric measurement was "gained" on the highest standard $(12.6 \mathrm{mM})$, meaning that the measurement of emission was calibrated on this light intensity.

\subsection{Standards}

Fresh, raw milk was centrifuged at $1000 \mathrm{~g}$ at $4{ }^{\circ} \mathrm{C}$ for $10 \mathrm{~min}$. Milk fat was aspirated from the milk. Centrifugation and aspiration of fat was repeated, this time at $1200 \mathrm{~g}$. The fat free milk was heat treated at $75^{\circ} \mathrm{C}$ for $30 \mathrm{~min}$. After cooling, Bronopol ${ }^{\circledR}$ (2-bromo-2nitropropan-1,3 diol) was added to a final concentration of $200 \mathrm{mg} / \mathrm{l}$

Standards were based on glycerol and fat free milk. A $14 \mathrm{mM}$ glycerol stock solution was prepared in the diluent, and further diluted with diluent to standards of $0,0.35,2.8,4.2,5.6,7.0,9.8$, and $12.6 \mathrm{mM}$. The fat free milk content was constant, i.e. $10 \%$ of the standards, right as milk made up $10 \%$ of the sample, due to dilution with water.

Every 96-well micro plate used for milk samples contained $2 \times 8$ standards as well.

\subsection{Validation of assay}

Linearity of the assay was determined by mixing milk samples with a relatively low fat content together with milk samples with a relatively high fat content.

The precision of the assay was estimated by five separate series each at one week-intervals. Each series consisted of two (plates) $\times 24$ milk samples that were analysed in three replicates on two subsequent days (i.e. each series numbered 288 single analyses).

Accuracy of the assay was assessed on 230 randomly chosen milk samples collected directly from our dairy barns, and analysed over five different days. The milking system is robotic, where recordings are automatically connected to the milk ID. The samples were analysed according to the present method and by the near IR technology (MilkoScan 4000, Foss Electric A/S, Hillerød, Denmark).

Sixty samples were selected equally amongst the two breeds and the 230 samples, i.e. $2 \times 10$ samples with low, $2 \times 10$ with middle and $2 \times 10$ with high values of the residuals from the regression TAG, mM vs. fat percentage including breed (see below). The samples were analysed for individual fatty acids after hydrolysis and the molar weight of the average TAG was calculated.

Analysis of fatty acids: Cream was separated from skim milk after centrifugation at $1700 \mathrm{~g}$ at $4{ }^{\circ} \mathrm{C}$ for $15 \mathrm{~min}$. The cream was centrifuged at $13,000 \mathrm{~g}$ at $20^{\circ} \mathrm{C}$ for $10 \mathrm{~min}$, followed by heating at $60{ }^{\circ} \mathrm{C}$ for $10 \mathrm{~min}$ and centrifugation at $13,000 \mathrm{~g}$ at $20^{\circ} \mathrm{C}$ for 10 min, (Feng, Lock, \& Garnsworthy, 2004; Murphy, Mcneill, Connolly, \& Gleeson, 1990). Fatty acid methyl esters were prepared by mixing $10 \mathrm{mg}$ of milk fat with $1 \mathrm{ml}$ pentane and $10 \mu \mathrm{l} 2.5 \mathrm{M}$ sodium methylate in methanol. Samples were mixed on a whirl mixer for $1 \mathrm{~min}$ and centrifuged, and the pentane supernatant was used for gas chromatography (GC) analysis (Badings \& C. Dejong, 1983). Samples were analysed with and without the addition of tridecanoin as internal standard. Fatty acids (FA) were identified, and content as g/100 g FA was calculated based on the use of external standards.

Gas chromatographic conditions: HP6890 GC-system (Hewlett Packard Co., Palo Alto, CA, USA) with a flame-ionisation detector and a Supelco SI 2560 column $(100 \mathrm{~m} \times 0.25 \mathrm{~mm} \times 0.20 \mu \mathrm{m}$, Supelco, Bellafonte, PA, USA). The inlet temperature was $275^{\circ} \mathrm{C}$ with a split ratio of 40:1, and the carrier gas helium with a constant flow of $1.5 \mathrm{ml} \mathrm{min}{ }^{-1}$. The starting temperature of $140{ }^{\circ} \mathrm{C}$ was held for 5 min and increased by $4{ }^{\circ} \mathrm{C}$ per minute to an end temperature of $240{ }^{\circ} \mathrm{C}$. The detector temperature was $300^{\circ} \mathrm{C}$.

Calculation of average molar weight: The molar content of each FA was calculated by dividing the content as $\mathrm{g} / 100 \mathrm{~g}$ FA by the molar weight of the corresponding FA TAG. The sum of these values was the total molar content of TAG per $100 \mathrm{~g}$ and the average molar weight was the reciprocal value multiplied by 100 .

\section{Results}

Table 1 summarises the results of the linearity experiment. The assay showed good linearity, the measured fat content of mixed samples revealed slightly higher levels than calculated, on average mixtures measured were 6-9\% higher than calculated.

The results of the precision determination, i.e. descriptive statistics, intra plate precision and inter day precision are given in Table 2. The chosen milk samples demonstrated a wide range of fat content, i.e. from $27 \mathrm{mM}$ to $109 \mathrm{mM}$ with a median value of $53 \mathrm{mM}$. The intra plate precision was on average a little below $5 \%(\mathrm{CV})$ and the between day precision on average a little above $5 \%$.

Table 3 shows the descriptive statistics of the 230 milk samples, where 173 samples originated from Friesian-Holstein cattle and 57 samples from Danish Jersey. Further, 166 samples were from 1st parity cows, 46 samples from 2nd parity cows, 14 samples from 3rd parity cows and 4 samples from 4th parity cows. The single regression TAG, $\mathrm{mM}$ vs. fat percentage (measured by IR spectrometry) explained $82 \%\left(R^{2}\right)$ of the variation in the material (Fig. 1). Including breed (and the interaction breed $\times$ fat percentage) increased the $R^{2}$ of the model to $85.3 \%$. Adding in days from calving did not improve the model further. Of the other constituents measured, milk yield and protein content were those that most improved the model although the increase in $\mathrm{R}^{2}$ was only from 85.3 to $86.6 \%$ and they did not account for the breed effect.

The calculated molar weight of the triglyceride-fat amongst the sixty samples selected for FA determination (MW mean 711.6, range 687-743) was not a significant explanatory variable in the regression of TAG, $\mathrm{mM}$ on fat percentage, breed and the interaction between these. The FA profile of the sixty milk samples was used as a basis for a grouping of FA (fractional amount). $C_{4}$ to $C_{10}, C_{11}$ to $C_{15}$, $C_{16}$ to $C_{18}$, and $C_{20}$ to $C_{24}$ acids were grouped and tested as predictors of the variation in the residuals from the TAG vs. fat percentage regression together with or without molar weight included. These groups did not account for any variation at all. The effects of relative distribution of the individual FA on the residuals between fat percentage and molar content of TAG, were then investigated. None of the individual FA convincingly explained the residual variation between the two determinations. However, a regression model containing five $\mathrm{FA}\left(\mathrm{C}_{18}, \mathrm{C}_{18: 3 \mathrm{~N} 6}, \mathrm{C}_{21}, \mathrm{C}_{22: 1 \mathrm{~N} 9}\right.$, and $\mathrm{C}_{20: 5 \mathrm{~N} 3}$ ) explained $50.1 \%$ of the variation in the residuals $\left(R^{2}=50.1 \%\right)$. Principal component analysis (PCA) confirmed this influence of individual FA. In a PCA including all individual FA, the proportion of the variation accounted for by the first 4 principal components was $59 \%$.

\section{Discussion}

The aim of this study was to develop a chemical method for quantification of milk TAG. It can be seen by the strong correlation with milk fat measured by IR spectrometry that this aim was achieved. The present method for quantification of milk TAG is, to our knowledge, the only chemical method described. Fat in milk is a delicate object for chemical determination for at least two reasons: the fat is protected in a chemically resistant and very hydrophobic compartment, i.e. the milk fat globules are protected by the 
Table 1

Linearity. Two groups of each sixteen samples (I and II) were selected and analysed together with mixtures of the samples ( $1+1$, between groups), all in three replicates.

\begin{tabular}{|c|c|c|c|c|c|}
\hline & \multicolumn{5}{|c|}{ Mesurements (mM) } \\
\hline & Mean, I (range) & Mean, II (range) & Mean $(a)$, mix (range) & Theoretical mean $(b)$, mix (range) & Deviation, $a / b$ (range) \\
\hline Plate $1, n=8$ & $33.0(21.9-40.2)$ & $43.1(24.7-53.9)$ & $40.2(27.5-47.3)$ & $38.0(26.8-45.3)$ & $1.06(1.02-1.14)$ \\
\hline Plate $2, n=8$ & $37.6(20.7-44.9)$ & $55.3(36.8-67.2)$ & $50.9(31.9-59.3)$ & $46.5(28.7-56.1)$ & $1.09(1.04-1.18)$ \\
\hline
\end{tabular}

Table 2

Intra plate and inter plate variation. Variation of determination was estimated on milk samples collected directly from the dairy barns (random sampling). Intra plate and inter plate precision were assessed in five series each spaced by one week. Each series contained 2 (plates) $\times 24$ milk samples $\times 3$ replicates analysed on two consecutive days, i.e. in total 240 different milk samples in $2 \times 3$ replicates ( $=1440$ analyses).

\begin{tabular}{|c|c|c|c|c|c|}
\hline TAG content, mM & Series 1 & Series 2 & Series 3 & Series 4 & Series 5 \\
\hline Minimum & 32.1 & 30.3 & 30.2 & 37.2 & 27.7 \\
\hline 0.10 Quantile & 39.4 & 41.1 & 40.6 & 42.2 & 34.2 \\
\hline 0.20 Quantile & 43.0 & 45.0 & 43.4 & 44.5 & 38.3 \\
\hline 0.50 Quantile & 51.0 & 57.6 & 56.4 & 55.2 & 45.1 \\
\hline 0.80 Quantile & 61.2 & 87.0 & 70.6 & 76.2 & 53.5 \\
\hline 0.90 Quantile & 67.4 & 95.5 & 90.2 & 83.4 & 59.0 \\
\hline Maximum & 93.7 & 117.8 & 108.6 & 101.8 & 70.7 \\
\hline $\begin{array}{l}\text { Intra plate precision, } \\
\qquad \mathrm{CV} \% ; N=96 ; n=3 \text { mean (median) }\end{array}$ & $4.2(3.5)$ & $4.2(3.6)$ & $4.2(3.6)$ & $5.3(4.7)$ & $6.5(6.0)$ \\
\hline $\begin{array}{l}\text { Between day precision, } \\
\quad \text { CV\% } N=144 ; n=2 \text { mean (median) }\end{array}$ & $4.2(3.7)$ & $4.4(3.7)$ & $4.3(3.3)$ & $7.1(4.4)$ & $5.5(4.5)$ \\
\hline
\end{tabular}

Table 3

Descriptive statistics of selected samples used for IR spectrometric fat analysis as well as chemical TAG analyses.

\begin{tabular}{llllll}
\hline Variable & $n$ & Mean & Median & Minimum & Maximum \\
\hline DFC & 230 & 170 & 149 & 2.8 & 502 \\
Milk yield, $\mathrm{kg}$ & 230 & 9.82 & 9.36 & 1.75 & 22.46 \\
Cells $\times 1000\left(\mathrm{ml}^{-1}\right)$ & 228 & 123.3 & 55.0 & 7.0 & 4211 \\
Protein $(\%)$ & 228 & 3.59 & 3.52 & 2.74 & 5.20 \\
Urea $(\mathrm{mM})$ & 228 & 4.08 & 4.04 & 1.26 & 6.25 \\
Lactose $(\%)$ & 228 & 4.95 & 4.96 & 4.55 & 5.34 \\
Fat $(\%)$ & 228 & 4.32 & 4.13 & 2.29 & 12.59 \\
TAG $(\mathrm{mM})$ & 230 & 57.2 & 52.5 & 27.7 & 116.4
\end{tabular}

$\mathrm{DFC}=$ days from calving; $\mathrm{TAG}=$ triacylglycerols.

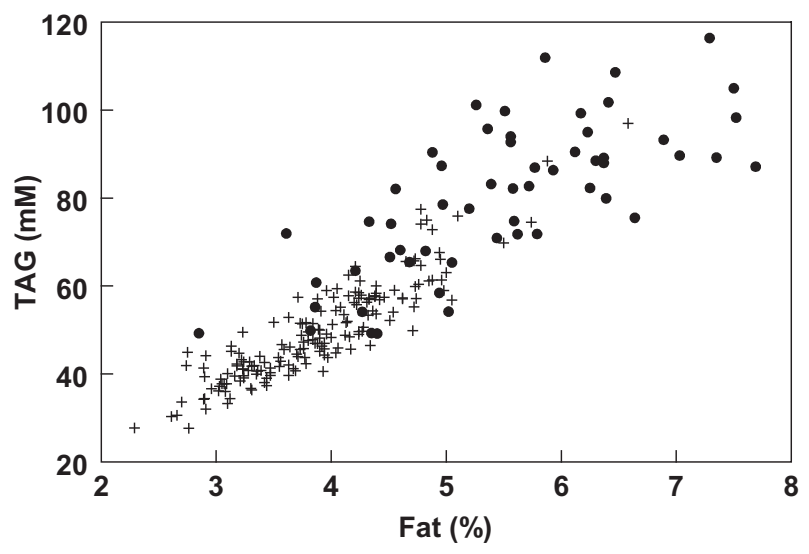

Fig. 1. Milk from Danish Jersey $(\bullet)$ and Friesian-Holstein $(+)$ was sampled at random on 5 days during 2 months. The enzymatic-fluorometric TAG analysis was compared with the fat percentage measured by IR-spectrometry (fat percentage). The regression equation was: TAG $=15.7 \times$ fat percentage $-10.1\left(R^{2}=0.822\right.$; $r=0.906 ; n=228 ; p<0.001$ ).

MFGM and, secondly, milk is extremely difficult to distribute in smaller quantities in a representative way, milk tends to fractionate easily to a fat fraction and a water phase, just as milk fat and protein adhere to surfaces of various materials.

Milk fat is fairly well protected against chemical and physical aggression. Freshly drawn milk contains only small amounts of free
FA, i.e. lipolysis is not advanced. Further, if the milking and storage procedures are appropriate, the milk can be kept for several days with little further development of free FA. It is well recognised, that natural milk contains indigenous lipases (or lipoprotein lipase) that under optimal conditions would be able to hydrolyse the innate content of TAG in hours. The majority of lipoprotein lipase activity seems to be associated with casein micelles in the milk serum (Hohe, Diminck, \& Kilara, 1985). The non-occurrence of spontaneous lipolysis has been ascribed to at least two factors: natural inhibition of the native lipoprotein lipase and physical constraints due to the MFGM. The inhibition of lipoprotein lipase may further be affected by indigenous components in the skim milk fraction or attached to proteins of the MFGM (Deeth \& Fitz-Gerald, 1975; Sundheim \& Bengtsson-Olivecrona., 1987). Inhibition of lipoprotein lipase may also be accomplished by free FA (end product inhibition) or even by blockage of enzymes involved in the process of reforming TAG (Olivecrona \& Bengtsson- Olivecrona, 1991). The MFGM is generally considered to be an effective protection against enzymatic action, mainly oxidation and lipolysis by lipoprotein lipases (Deeth \& Fitz-Gerald, 1995; Olivecrona \& Bengtsson-Olivecrona, 1991; Walstra \& Jenness, 1984) as long as it is not disrupted by extreme temperatures, mechanical stress or strong chemical agents.

The vast majority of TAG is situated in the internal part of globules which are enveloped by the MFGM the latter being resistant to lipoprotein lipases and lipases. Some sort of disruption of the MFGM is necessary if a chemical determination of TAG is intended. Various forms of physical stress, e.g. pumping, agitation and homogenisation, and termal treatment, like freezing, refrigeration, and heating have been shown to damage the membrane to varying extent. Heat treatment, especially, leads to significant compositional changes in the MFGM, i.e. loss of original membrane components, such as TAG, phospholipids, lipoproteins and proteins (Houlihan, Goddard, Kitchen, \& Masters, 1992; Houlihan, Goddard, Nottingham, Kitchen, \& Masters, 1992) because the fat globules coalesce and the surface is reduced. In addition, a well known effect of heating is that milk serum proteins will interact with the MFGM (Kim \& Jimenez-Flores, 1995; Lee \& Sherbon, 2002).

Chemical disruption of the MFGM is another way to get access to the TAG content of the globule. Most analyses of MFGM reveal 
that it consists mainly of protein and lipids (approx. 90\%). The TAG content seems variable, presumably due to difficulties in separating from the core content; however, the phospholipid content seems to be less variable, being about 26 to $31 \%$ of MFGM fat (Keenan \& Mather, 2006) and phospholipids furthermore seem to be an essential matrix of other MFGM components (Lopez et al., 2010). Several studies have described that milk fat is more exposed to lipolysis by lipoprotein lipases and lipases when micro organisms producing phospholipase C (EC 3.1.4.3) are present or isolated phospholipase $C$ is added to milk (reviewed by Deeth \& Fitz-Gerald, 1995). The MFGM phospholipids are primarily phosphatidyl choline, phosphatidyl ethanolamine, and sphingomyelin, all obvious substrates for phospholipase C. Phospholipases apparently disrupt the integrity of the MFGM and expose the membrane fat and the core fat to degradation (Chrisope \& Marshall, 1976). Lipases and lipoprotein lipases obviously have different affinity for specific TAG, presumably due to the composition of the TAG, i.e. specific fatty acids (size, number of double or triple bonds) and the mutual placing on the glycerol molecule. The present use of both a lipase and a lipoprotein lipase was intended so as to counter this enzyme-substrate preference.

The regression of individual FA on the residuals between the molar content of TAG and fat percentage revealed that FA do play an important role in the deviation between methods. It is not likely

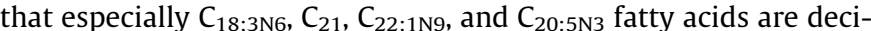
sive per se; together they constitute $0.09 \%$ of all fatty acids, but these FA indicate the existence of important components co-linearily linked to the acids under consideration. This is not obvious in the present material due to a limited number of samples and analytical constraints.

The present chemical determination of TAG gives the quantity on a molar basis (mM). We acknowledge that it is a bit surprising that the molar weight of selected milk samples alone or with the grouping of FA did not improve the regression between the two methods of determination. However, the IR-spectrometric determination of fat (as any other determination) reports the result in weight percentage because it is calibrated against gravimetric determinations. Consequently, if the molar weight of a certain fat is low, the number of moles will be higher than a similar amount of fat where the molar weight is high. Jersey cows are known to produce milk containing TAGs with lower molar weight, because the fractional part of short-chain FA is higher, and the fractional part of longer chain-length FA is lower than milk from Friesian-Holstein (Beaulieu \& Palmquist, 1995; Stull \& Brown, 1964; White et al., 2001). A part of the disparity between IR-spectrometric and the present enzymatic-fluorometric measurement may be founded on the fact that IR instruments are individually calibrated against gravimetric methods (e.g. Röse Gottlieb, etc.) not taking molar weight nor breed of the milk producing cows into consideration.

The present chemical quantification of milk TAG will in no way be an alternative to or competitive to the widely used IR technology used in practical dairy business. The present method is evidently a laboratory technique, more time and personnel consuming, using sophisticated chemicals and gear not suitable for exposure to practical farm conditions or large-scale, fast and inexpensive analyses. On the other hand, using the outlined methodology makes it possible to perform hundreds of analyses per day, you only need very small quanta of milk, and the present method gives additional information (the molar content) compared to other methods. The present method may substitute for the Gerber method or the Röse-Gottlieb method, usually used for calibration of fast, commercial methods like the IR. Furthermore, the present method, may find application in animal science (feeding, breeding, and physiology) and dairy science where the additional information is estimated.

\section{Acknowledgements}

Carsten Berthelsen is kindly acknowledged for excellent technical assistance and skilled analytical work. This study, which was part of the Biosens project, was funded by the Danish Ministry of Food, Agriculture and Fisheries and the Danish Cattle Association.

\section{References}

Badings, H. T., \& Dejong, C. (1983). Glass-capillary gas-chromatography of fatty-acid methyl-esters - A study of conditions for the quantitative-analysis of shortchain and long-chain fatty-acids in lipids. Journal of Chromatography, 279, 493506.

Beaulieu, A. D., \& Palmquist, D. L. (1995). Differential effects of high fat diets on fatty acid composition in milk of Jersey and Holstein cows. Journal of Dairy Science, $78,1336-1344$

Chrisope, G. L., \& Marshall, R. T. (1976). Combined action of lipase and microbial phospholipase $\mathrm{C}$ on a model fat globule emulsion and raw milk. Journal of Dairy Science, 59, 2024-2030.

Christie, W. W. (1994). Composition and structure of milk lipids. In: P.F. Fox (Ed.), Advanced dairy chemistry. Vol. 2. Lipids (2nd ed., pp. 1-21). Chapman \& Hall.

Christie, W. W., \& Clapperton, J. L. (1983). Cited by Davies et al. (1983).

Danthine, S., Blecker, C., Paquot, M., Innocente, N., \& Deroanne, C. (2000). Progress in milk fat globule membrane research: A review. Lait, 80, 209-222.

Davies, D. T., Holt, C., \& Christie, W. W (1983). The composition of milk. In: T. B. Mepham (Ed.), The biochemistry of lactation. Amsterdam, New York: Elsevier.

Deeth, H. C., \& Fitz-Gerald, C. H. (1995). Lipolytic enzymes and hydrolytic rancidity in milk and milk products. In: P. F. Fox (Ed.). Advanced dairy chemistry. Vol. 2. Lipids (2nd ed., pp. 255-261). Chapman \& Hall.

Deeth, H. C., \& Fitz-Gerald, C. H. (1975). Factors governing the susceptibility of milk to spontaneous lipolysis. International Dairy Federation, 86, 24-34.

Evers, J. M. (2004). The milkfat globule membrane - Compositional and structural changes post secretion by the mammary secretory cell. International Dairy Journal, 14, 661-674.

Feng, S., Lock, A. L., \& Garnsworthy, P. C. (2004). Technical note: A rapid lipid separation method for determining fatty acid composition of milk. Journal of Dairy Science, 87(11), 3785-3788.

Gerber, N. (1891). Neuer butyrometer, Patent CH2621, (1891-01-31) Bern: Eingenössissches Institut für Geistiges Eigentum.

Hohe, K. A., Diminck, P. S., \& Kilara, A. (1985). Milk lipoprotein lipase distribution in the major fractions bovine milk. Journal of Dairy Science, 68, 1067-1073.

Houlihan, A. V., Goddard, P. A., Kitchen, B. J., \& Masters, C. J. (1992). Changes in structure of the bovine milk fat globule membrane on heating whole milk Journal of Dairy Research, 59, 321-329.

Houlihan, A. V., Goddard, P. A., Nottingham, S. M., Kitchen, B. J., \& Masters, C. J. (1992). Interaction between the bovine milk fat globule membrane and skim milk components on heating whole milk. Journal of Dairy Research, 59, 187-195.

IDF (1996). International Standard ID. Milk-Determination of fat content - Gravimetric method (Röse Gottlieb reference method). Brussels, Belgium: International Dairy Federation.

IDF (2000). International Standard 141C. Whole milk-Determination of milkfat, protein and lactose content-Guidance on the operation of mid-infrared instruments. Brussels, Belgium: International Dairy Federation.

Keenan, T. W., \& Mather, I. H. (2006). Origin of milk fat globules and the nature of the milk fat globule membrane. In: P. F. Fox, P. L. H. McSweeney (Eds.), Advanced dairy chemistry. Vol. 2. Lipids (3rd ed.). New York, USA: Springer Science+Business Media, Inc.

Kim, H.-H. Y., \& Jimenez-Flores, R. (1995). Heat induced interactions between the proteins of milk fat globule membrane and skim milk. Journal of Dairy Science, $78,24-35$.

Kuzdzal-Savoie, S., Kuzdral, W., Langlois, D., \& Trehin, J. (1973). Nonglyceride constituents of the lipid fraction of milk. In C. Galli, G. Jacini, \& A. Pecile (Eds.) Dietary lipids in postnatal development (pp. 1-21). New York: Raven Press.

Lee, S. J., \& Sherbon, J. W. (2002). Chemical changes in bovine milk fat globule membrane caused by heat treatment and homogenization of whole milk Journal of dairy Research, 69, 555-567.

Lopez, C., Madec, M.-N., \& Jimenez-Flores, R. (2010). Lipid rafts in the bovine milk fat globule membrane revealed by the lateral segregation of phospholipids and heterogeneous distribution of glycoproteins. Food Chemistry, 120, 22-33.

MacGibbon, A. K .H., \& Taylor, M. W. (2006). Composition and structure of bovine milk lipids. In: P. F. Fox, P. L. H. McSweeney (Eds.), Advanced dairy chemistry (Vol. 2, 3rd ed.). New York, USA: Springer Science+Business Media, Inc.

Mather, I. H. (2000). A review and proposed nomenclature for major proteins of the milk-fat globule membrane. Journal of Dairy Science, 83, 203-247.

McPherson, A. V., \& Kitchen, B. J. (1983). Reviews of the progress of dairy science: The bovine milk fat globule membrane - It's formation, composition, structure and behaviour in milk and dairy products. Journal of Dairy Research, 50, 107133.

Murphy, J. J., Mcneill, G. P., Connolly, J. F., \& Gleeson, P. A. (1990). Effect on cow performance and milk-fat composition of including full fat soybeans and rapeseeds in the concentrate mixture for lactating dairy-cows. Journal of Dairy Research, 57(3), 295-306. 
Olivecrona, T., \& Bengtsson-Olivecrona, G. (1991). Lipase. In: P. F. Fox (Ed.), Food enzymology (Vol. 1, pp. 62-78). London, New York: Elsevier Applied Science. Parodi, P. W. (1982). Positional distribution of fatty acids in triglycerides from milk of several species of mammals. Lipids, $17,437-442$.

Patton, S., \& Jensen, R. G. (1974). Lipid metabolism and membrane functions of the mammary gland. Progress in the Chemistry of Fats and Other Lipids, 14, 163-277.

Patton, S., \& Keenan, T. W. (1975). The milk fat globule membrane. Biochimica et Biophysica Acta, 415, 273-309.

Rombaut, R., \& Dewettinck, K. (2006). Properties, analysis and purification of milk polar lipids. International Dairy Journal, 16, 1362-1373.

Stull, J. W., \& Brown, W. H. (1964). Fatty acid composition of milk. II Some differences in common dairy breeds. Journal of Dairy Science, 47, 1412.
Sundheim, G., \& Bengtsson-Olivecrona, G. (1987). Hydrolysis of bovine milk fat globules by lipoprotein lipase: Inhibition by proteins extracted from milk fat globule membrane. Journal of Dairy Science, 70, 1815-1821.

Walstra, P. (1995). Physical Chemistry of milk fat globules. In: P. F. Fox (Ed.), Advanced dairy chemistry. Vol. 2. Lipids (2nd ed., pp. 131-178). Chapman \& Hall. Walstra, P., \& Jenness, R. (1984). Dairy Chemistry and Physics. New York, NY: John Wiley and Sons, Publ. Inc..

White, S. L., Bertrand, J. A., Wade, M. R., Washburn, S. P., Green, J. T., Jr., \& Jenkins, T. C. (2001). Comparison of fatty acid content of milk from Jersey and Holstein cows consuming pasture or a total mixed ration. Journal of Dairy Science, 84, 2295-2301. 